\title{
Teaching NeuroImages: DWI and EEG findings in Creutzfeldt-Jakob disease
}

Aravind Ganesh, MD, Lisa C. Hoyte, MD, DPhil(Oxon), Yahya Agha-Khani, MD, FRCPC, and Michael M.C. Yeung, MD, FRCPC

Neurology ${ }^{\circledR}$ 2018;90:e1450-e1451. doi:10.1212/WNL.0000000000005336

A 62-year-old woman, previously healthy, presented with 3 weeks of progressive short-term memory loss, dyscalculia, dysgraphia, appetite loss, and frequent episodic left arm dystonic posturing and eyebrow elevation. On examination, she also had finger agnosia, dysarthria, agraphesthesia, and astereognosis bilaterally, with myoclonus, ideomotor apraxia (left worse), and wide-based gait. EEG showed slowing and periodic lateralized discharges over the right hemisphere with triphasic morphology, less often involving the left, reflecting clinical asymmetry (figure 1). ${ }^{1}$ MRI brain showed diffusion restriction in the bilateral basal ganglia with cortical ribboning more prominent on the right involving several gyri, consistent with Creutzfeldt-Jakob disease (figure 2). ${ }^{2}$

\section{Author contributions}

Dr. Ganesh: concept, acquisition of data, and writing the initial drafts of the manuscript. Dr. Hoyte: concept, acquisition of data, and writing the initial drafts of the manuscript. Dr. Agha-Khani: acquisition of data and critical revision of manuscript for intellectual content. Dr. Yeung: concept and critical revision of manuscript for intellectual content.

\section{Study funding}

No targeted funding reported.

\section{Disclosure}

A. Ganesh serves on the Neurology ${ }^{\circledR}$ Resident \& Fellow Section's editorial board. L. Hoyte, Y. Agha-Khani, and M. Yeung report no disclosures relevant to the manuscript. Go to Neurology.org/N for full disclosures.

\section{References}

1. Wieser HG, Schindler K, Zumsteg D. EEG in Creutzfeldt-Jakob disease. Clin Neurophysiol 2006;117:935-951.

2. Vitali P, Maccagnano E, Caverzasi E, et al. Diffusion-weighted MRI hyperintensity patterns differentiate CJD from other rapid dementias. Neurology 2011;76:1711-1719.

\author{
Correspondence \\ Dr. Yeung \\ michael.yeung@ \\ albertahealthservices.ca
}

\section{MORE ONLINE}

$\rightarrow$ Teaching slides

links.lww.com/WNL/A354 


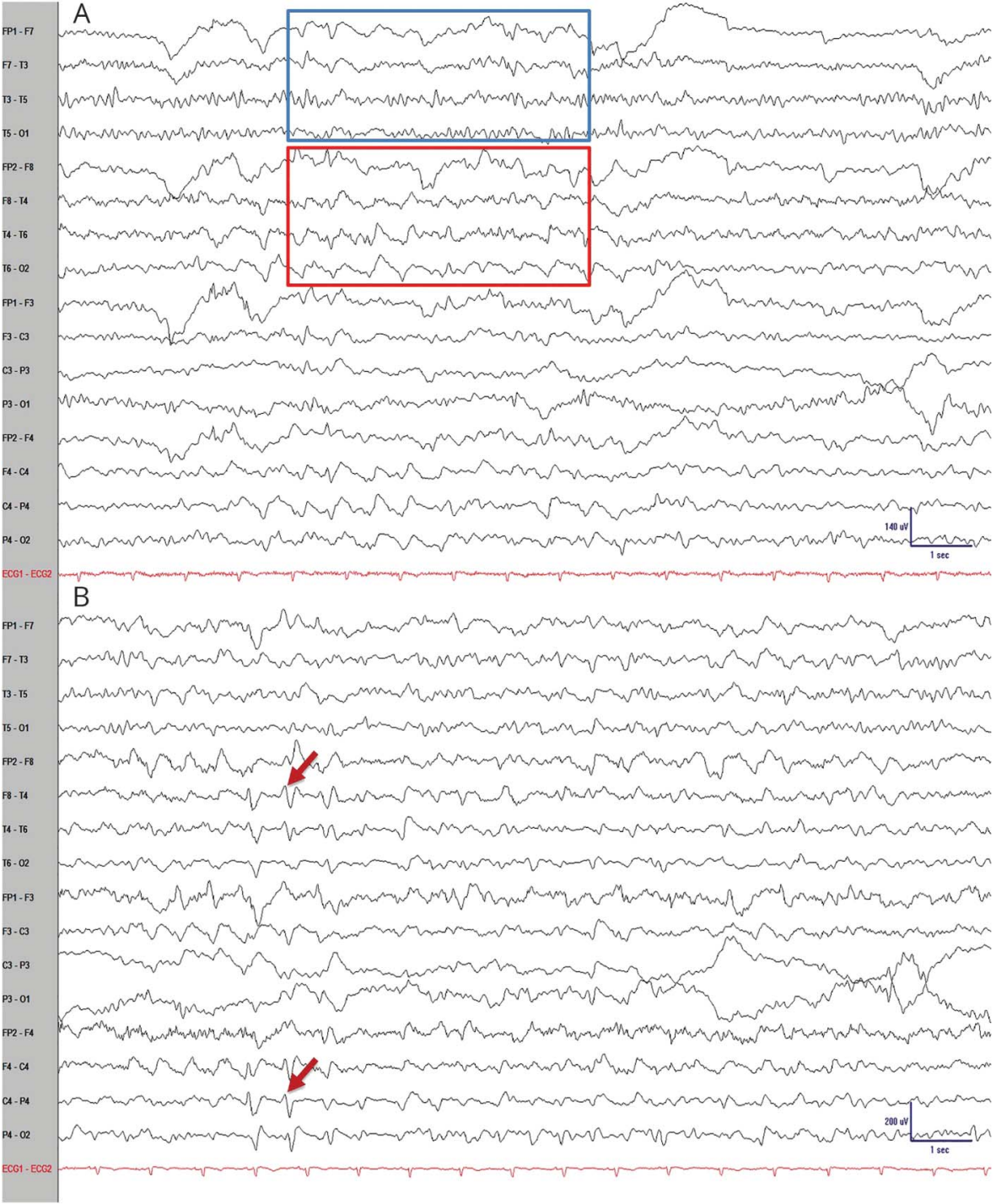

Representative epochs of the EEG show (A) posterior alpha rhythm on the left vs thetadelta slowing over the right hemisphere and (B) periodic lateralized discharges over the right hemisphere with triphasic morphology.

Figure 2 MRI findings of cortical and striatal diffusion restriction in Creutzfeldt-Jakob disease

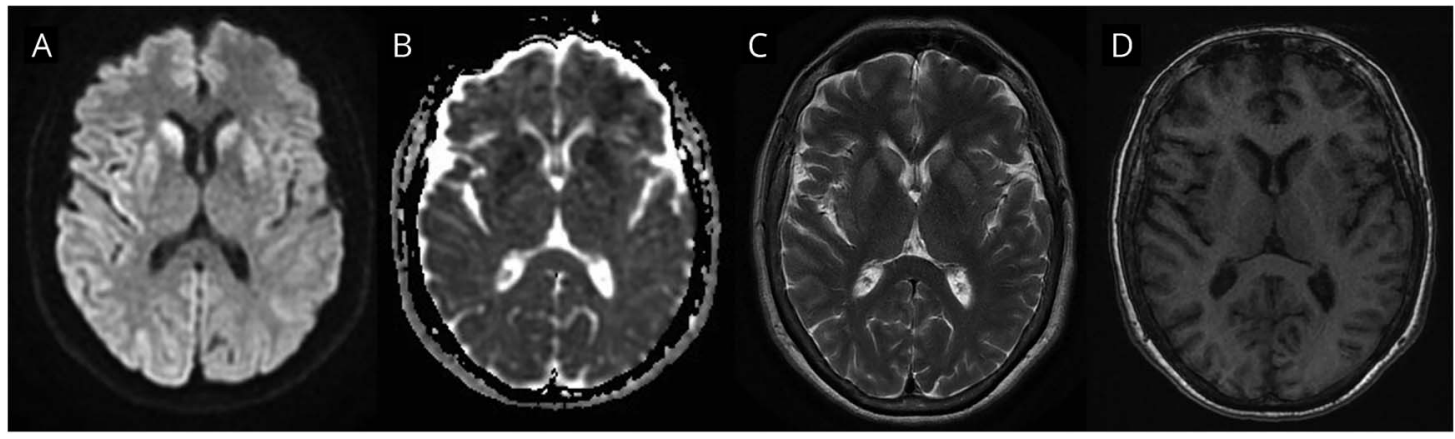

Axial sections on (A) diffusion-weighted imaging, (B) apparent diffusion coefficient, (C) T2-weighted, and (D) T1-weighted MRI sequences show true diffusion restriction in the bilateral caudate and putamen and multiple gyri, more on the right (cortical ribboning), but without other changes on T2 or T1. 


\section{Neurology}

Teaching NeuroImages: DWI and EEG findings in Creutzfeldt-Jakob disease

Aravind Ganesh, Lisa C. Hoyte, Yahya Agha-Khani, et al.

Neurology 2018;90; 1450 -e1451

DOI 10.1212/WNL.0000000000005336

This information is current as of April 16, 2018

\section{Updated Information \&} Services

References

Citations

Subspecialty Collections

Permissions \& Licensing

Reprints including high resolution figures, can be found at: http://n.neurology.org/content/90/16/e1450.full

This article cites 2 articles, 1 of which you can access for free at: http://n.neurology.org/content/90/16/e1450.full\#ref-list-1

This article has been cited by 2 HighWire-hosted articles: http://n.neurology.org/content/90/16/e1450.full\#\#otherarticles

This article, along with others on similar topics, appears in the following collection(s):

\section{DWI}

http://n.neurology.org/cgi/collection/dwi

EEG

http://n.neurology.org/cgi/collection/eeg_

Prion disease; see Infections/prion

http://n.neurology.org/cgi/collection/prion_disease

Information about reproducing this article in parts (figures,tables) or in its entirety can be found online at:

http://www.neurology.org/about/about_the_journal\#permissions

Information about ordering reprints can be found online:

http://n.neurology.org/subscribers/advertise

Neurology ${ }^{\circledR}$ is the official journal of the American Academy of Neurology. Published continuously since 1951, it is now a weekly with 48 issues per year. Copyright @ 2018 American Academy of Neurology. All rights reserved. Print ISSN: 0028-3878. Online ISSN: 1526-632X.

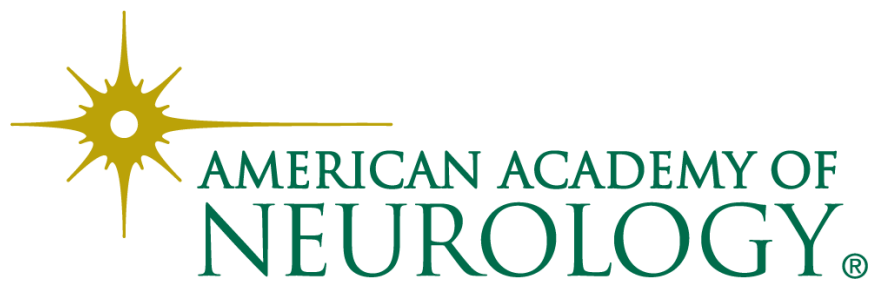

